\title{
Recovery of Unsold Food from Three Agri-Food Industries (SOCOCE, COQUIVOIRE and SCB) for the Feeding of the Abidjan Zoo Animals
}

\section{Sandotin Lassina Coulibaly ${ }^{*}$, Kouakou Sylvain Akpo ${ }^{2}$, N'Da Akoua Alice Koua-Koffi ${ }^{1}$, Doué Barnabé Digbe ${ }^{3}$, Lacina Coulibaly²}

\author{
${ }^{1}$ UFR-Agronomic, Forestry and Environmental Engineering, Department of Environment and Sustainable Development, \\ University of Man, Man, Côte d'Ivoire \\ ${ }^{2}$ UFR - Environmental Sciences and Management, Laboratory of Environment and Aquatic Biology, Nangui Abrogoua University, \\ Abidjan, Côte d'Ivoire \\ ${ }^{3}$ Agent of the National Zoo of Abidjan, Côte d'Ivoire \\ Email: ^Sandotin.coulibaly@univ-man.du.ci, ^sandotinc@gmail.com
}

How to cite this paper: Coulibaly, S.L. Akpo, K.S., Koua-Koffi, N’D.A.A., Digbe, D.B. and Coulibaly, L. (2021) Recovery of Unsold Food from Three Agri-Food Industries (SOCOCE, COQUIVOIRE and SCB) for the Feeding of the Abidjan Zoo Animals. Journal of Agricultural Chemistry and Environment, 10, 415-427. https://doi.org/10.4236/jacen.2021.104027

Received: August 25, 2021

Accepted: October 31, 2021

Published: November 3, 2021

Copyright $\odot 2021$ by author(s) and Scientific Research Publishing Inc. This work is licensed under the Creative Commons Attribution International License (CC BY 4.0).

http://creativecommons.org/licenses/by/4.0/ (c) (i) Open Access

\begin{abstract}
The waste of foodstuffs is increasing in the agri-food industries. This is reflected in the increasing volume of their waste. Food is thrown away on criteria that have nothing to do with its nutritional quality. In most cases, the criteria are shape, color and stains. In order to reduce this waste, a way of valorization was investigated. This paper focuses on waste reduction through feeding the Abidjan zoo animals with the unsold products of three agro-industries. The unsold products collected by the zoo were characterized over an 8-year period (2011 to 2019). Deaths and births were recorded. The food needs met by the unsold products harvested were evaluated and the economic gains estimated. The results showed that the food recovered by the Abidjan Zoo at SOCOCE contained $34.94 \%$ fruit, $38.58 \%$ vegetable and $23.47 \%$ meat products. At SCB and Coquivoire the donations are estimated at 2 tons of bananas and 1.5 tons of chickens (smoked and cold chicken) respectively. These donations allowed the Zoo to save $25.94 \%$ of its budget allocated to animal feed. The diversity of the food collected has a positive impact on the quality of life of the animals at the Zoo. This is reflected in an increase in the number of births from 0 to 12 per year and a decrease in mortality of $90 \%$.
\end{abstract}

\section{Keywords}

Agri-Food, Unsold Food, Zoo, Waste, Animal Feed 


\section{Introduction}

Global waste generation has doubled over the past decade and is expected to reach $69 \%$ by 2025 , if trends continue [1]. Among this waste, there appears unsold food from marketing structures and agri-foods industries which constitute food loss and waste.

[2] has shown that approximately 38,000 large supermarkets in the United States generate $1,100,000,000$ pounds of produce that are currently sent to landfills. His analysis suggests that repurposing surplus produce from supermarket discards can have significant beneficial outcomes for new food markets and the environment. Worldwide, about 4.5 trillion tons of food are produced every year, which is nearly twice as much as the amount required to satisfy the food needs of the world [3]. Food waste is a real problem in our current societies which has significant social, environmental and economic consequences. Food losses and waste tend to become a symbol of the inefficiency, unfairness and unsustainability of food systems. The reduction of waste is one of the fundamental issues in a sustainable modern society, and when it comes to food, the implications are even broader [4] [5]. Its waste, due to its natural composition, accumulates in dumpsters and then in landfills. It begins to release landfill gas, which in many ways affects global warming. One-third of the world's food production is wasted, all along the food chain, from production to consumption. This represents 1.3 billion tons of food that is lost each year according to [3] [6]. In the countries of Asia and Africa, food waste is between 120 and $220 \mathrm{~kg}$ per inhabitant per year with a variation according to the regions [7]. Face with the quantities concerned, it is necessary to find solutions to recover this waste in order to make maximum use of its potential. Many studies have shown that food waste is an economic resource that must be valued [7] [8]. Thus, when the use of human food is no longer possible, economic valuation through animal feed can be considered [9] [10] [11]. Feeding unsold food to animals is an alternative to systematic landfilling. This form of valorization has led to reflection on their food value and, consequently, their potential economic interest.

Ivory Coast, a country in West Africa, like other countries, is not on the sidelines. There are food marketing structures such as Central West Commercial Company (SOCOCE), Banana Crop Study and Development Company (SCB) and Ivorian Company of Animal Productions (COQIVOIRE/SIPRA) which produce waste from their unsold product that they are forced to manage. While the $\mathrm{Ab}$ idjan zoo (Ivory Coast) is home to several species of animals that must be fed regularly. Using these unsold products for feeding the zoo animals could lower the pressure on food production and reduce pressure on natural resources for a few years [12]. The objective of this study is to show the importance of unsold products from these structures in feeding the animals of the zoo of Abidjan. Specifically, it is a question of 1) evaluating the composition of these unsold products, 2) estimating the quantities, 3) showing the impact of the use of this unsold food in animal feeding in the zoo. 


\section{Material and Methods}

\subsection{Materials}

The structures producing unsold food are the SCB (Société de Culture Bananière) is an agro-industry specialized in the production, packaging and export of banana, pineapple, papaya and mango on six (06) sites in the south of the Ivory Coast. It also has a laboratory of Vitroplants. Then SIPRA (Société Ivoirienne de Productions Animales) aims at developing a modern poultry industry. It works in all the links of the poultry sector. It has corn plantations, feed factories, breeding flocks, a hatchery, broiler and layer farms, a slaughterhouse, a meat laboratory, an analysis and quality laboratory, an egg packaging center and its own distribution networks for all its products. And finaly SOCOCE (Société Commerciale du Grand Ouest) was a first supermarket chain in Côte d'Ivoire. This space, built on more than 20,000 square metres, was even the first hypermarket in West Africa. The shopping mall offers shops, supermarket, restaurants and cinema. These three structures produce unsold food which is recovered by the Abidjan Zoo in order to feed the animals. The National Zoo Abidjan (Ivory Coast) is located in Cocody municipality. It covers an area of nine (09) hectares, four of which are used and occupied by buildings and cages. It is home of three groups of animals (mammals, reptiles and birds).

For this study, several facilities were used. For waste sorting, transport, cutting, weighing and unsold food conservation, the equipment used consists of:

- Protective equipment: gloves, bleach, black tarpaulin to cover waste.

- Material and means of transport: one (1) tricycle, one (1) dumpster or tarpaulin, plastic crates, wooden crates for transporting SCB bananas.

- Processing equipment: knives to cut fruit and vegetables, one (1) scale for the various weighing, ALMEPHON 480 to accelerate ripening.

- Conservation equipment: three (3) freezers, one (1) warehouse.

\subsection{Data Collection and Analysis}

The statistical data analysis was carried out using the Excel program. Questionnaires were used as a research tool and focused only on interviews and meetings with those in charge of the donor structures. Information collected was used to characterized unsold items made available to the zoo of Abidjan. The collection of unsold goods was done two or five times a month depending on the quantity available. Once the unsold stock is removed from the shelves or the sales system, the zoo agents are contacted by the managers of the donor structures. On-site, the food was sorted and weighed by the zoo agents before being transported. On arrival at the Zoo, the food was washed and again sorted into two groups. The first group was eaten as soon as possible. The second group was packaged and stored in the refrigerators if necessary to be used as needed. The impacts of unsold products from these agrifoods (SOCOCE, SCB, and COQIVOIRE) on the feeding of the zoo's animals were evaluated. Information was recorded during a 
daily and weekly process with the animal tracking sheets available at the zoo. On these sheets, births, deaths, and the nature of the care given to the animals were reported. The financial gain was calculated taking into account parameters such as the unit costs of feed. The cost of transport was almost identical and was not included in the calculation. In addition, labor was not taken into account because the workers are contract workers with fixed salaries.

\section{Results and Discussion}

\subsection{Results}

\subsubsection{Abidjan Zoo Population}

In 2011, there were 151 animals alive at Abidjan zoo (Figure 1). This total includes 16 herbivores, 81 carnivores and 52 omnivores. The graph shows that carnivores are the most numerous with a rate of $54 \%$ of the zoo's animals. Then come the omnivores (35\%) and finally the herbivores with $11 \%$. One of the zoo most important roles is to manage these as a population, to ensure that the population remains healthy, genetically-diverse, and self-sustaining [13].

\subsubsection{Composition Unsold Items and Quantities from the Three (3) Agrifoods}

Several types of unsold products have been identified at SOCOCE, the main unsold products are fruits and vegetables (watermelon, melon, radish, cauliflower, turnip, grape, kiwi, etc.), to which are added bread as a plant product, and animal by-products which consist of meat, fish, milk and egg products. As for SCB, it produces fruits including dessert bananas, on six (06) sites, that's of Dabou is made up of two kinds of waste that are profitable for the zoo, namely fruit sorting discrepancies, which are non-exportable fruits and fruit waste (debris of pads, stems or fruit that cannot be eaten by human). The COQIVOIRE, a subsidiary of SIPRA, produces whole smoked and fresh chickens, poultry cuts and $100 \%$ poultry meat products. The weight of unsold items collected varies monthly from 1000 up to $1500 \mathrm{~kg}$. Figure 2 shows the proportions of the different categories of unsold products from SOCOCE and collected by the Zoo from 2011 to 2016 . The percentage share of unsold food collected by SOCOCE in the selected food groups was the following: vegetables $38.58 \%$, fruits $34.94 \%$ and meat $26.47 \%$. This study showed the largest waste of vegetable and fruits. At SCB of Dabou, the quantity of dessert bananas is estimated at two (2) tonnes per month of non-exportable fruits. As for fruit waste, their quantity is estimated at one tone depending on the surface area of the plots and the bad weather which causes the fall of banana trees not yet formed. In addition, SCB sometimes delivers premium quality dessert bananas for export, in quantities of 60 up to 2000 boxes, three or four times a year. COQUIVOIRE's unsold products are estimated at three (03) tonnes per month. The unsold goods from COQIVOIRE made available to the zoo of Abidjan are estimated at 1.500 tonnes per month. All of these quantities are averages obtained over the 8 years of study from 2011 to 2019. 


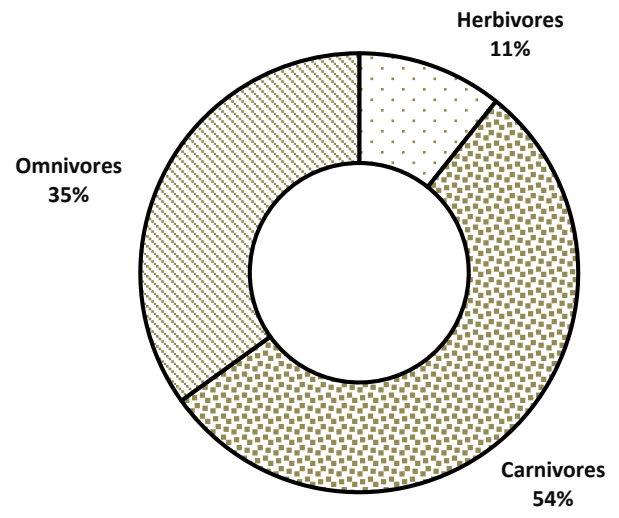

Figure 1. Zoo animals classified according to their dietary habits.
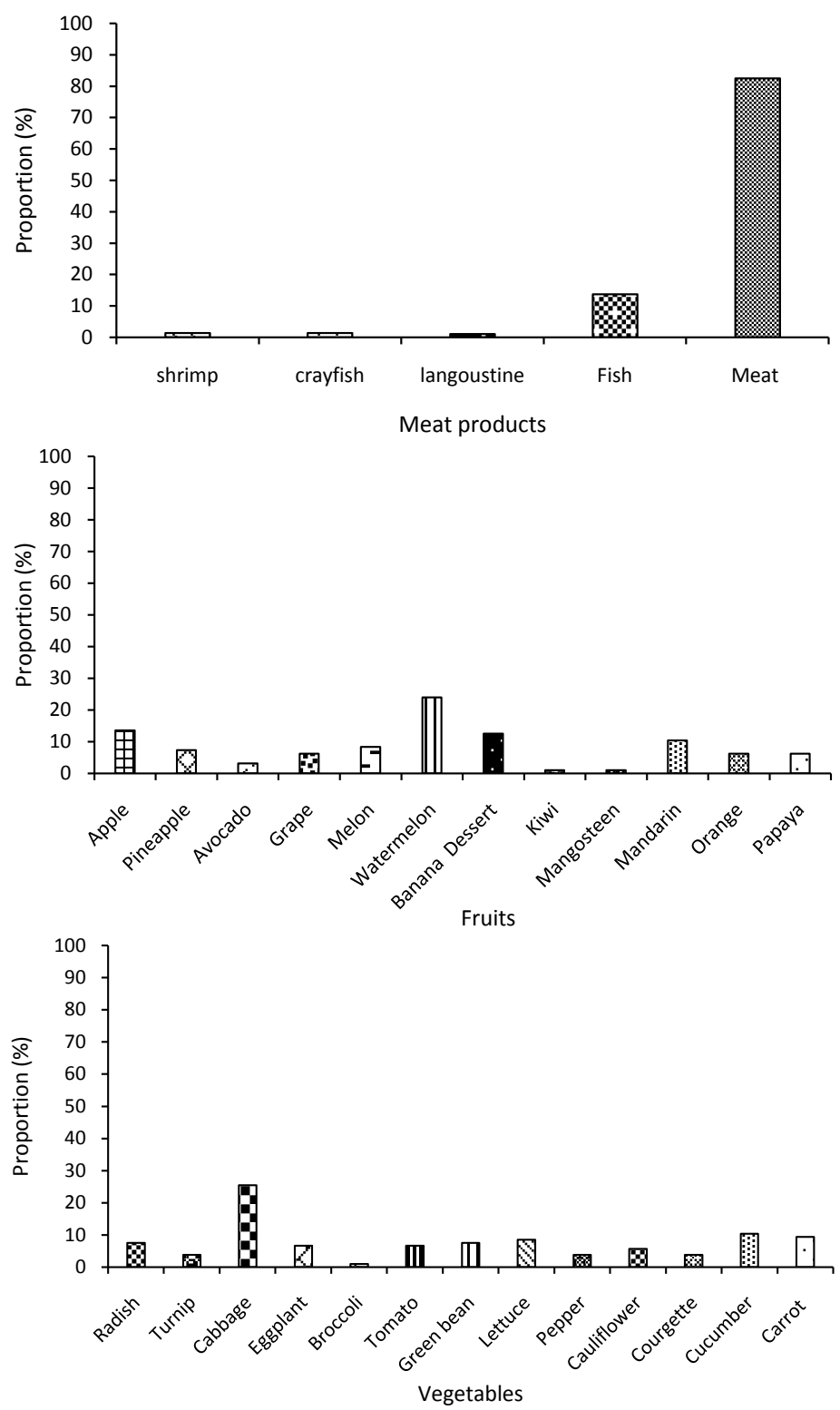

Figure 2. Monthly estimate of the deposit of unsold items taken from SOCOCE by the Zoo from 2011 to 2019. 


\subsubsection{Valuation and Comparative Studies of Unsold Goods in Relation to the Zoo's Needs}

SCB's dessert bananas are intended for feeding primates (chimpanzees, monkeys), herbivores (zebra, bushbucks, and duikers), small carnivores (civets, mongooses and genets) and certain birds (parrots, etc.). The unsold products of COQIVOIRE which are chickens are used as food for crocodiles, monitor lizards and small carnivores. SOCOCE's unsold products are intended for feeding primates, herbivores and certain carnivores. Of the 151 animals at the Abidjan National Zoo, 95\% is fed with unsold products from these three Agrifood. Figure 3 shows the difference between the zoo's needs and the donations of the three agro-industries for feeding the zoo's animals. For fruits, it can be seen that there is no external input for yams, peanuts and onions. Also for carrots, oranges, cucumbers and papayas, external contributions cover one third of the needs. For cabbages, however, the zoo's needs are fully met. Observations on meat requirements show that for a monthly estimated need for beef and mutton of $1.162 \mathrm{~kg}$, only $240 \mathrm{~kg}$ are provided by donations from agro-industries. Fish and chicken needs are compensated for at 50 and $112.2 \%$ respectively. Cereals are almost non-existent in the donations. Indeed, only contributions in the needs of wheat have been observed, that is to say about a third of the needs of the zoo. On the other hand, unsold foodstuffs can compensate for the lack of certain fruits and vegetables (Figure 3), given their similar nutritional value. These include bananas, which are used in the diet of herbivores (elephants, zebras) and certain omnivores (monkeys, Civets).

\subsubsection{Impact of the Use of Unsold Food to Feed the Zoo's Animals}

The using of unsold food for the zoo is being felt financially, in reproduction and animal mortality rates.

\section{1) Financial plan}

Figure 4 shows the financial impact of using unsold products from SCB, SOCOCE and COQIVOIRE/SIPRA. The zoo's annual expenses for feeding the animals are estimated at \$162,037.8 Dollar (USD). The financial evaluation of the donations is $42,037.2$ Dollar (USD). This allows a reduction of $25.94 \%$ of the expenses.

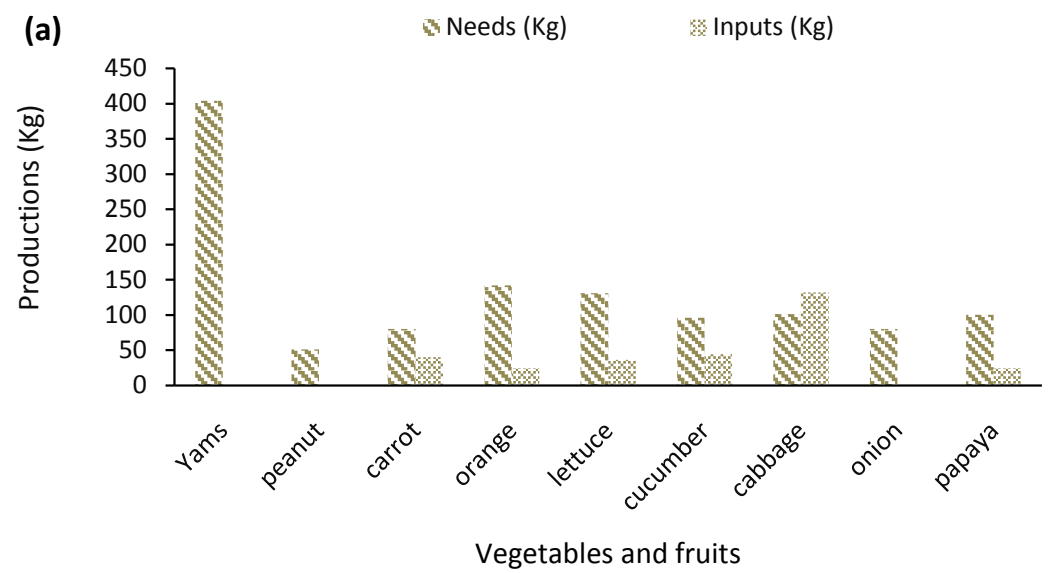



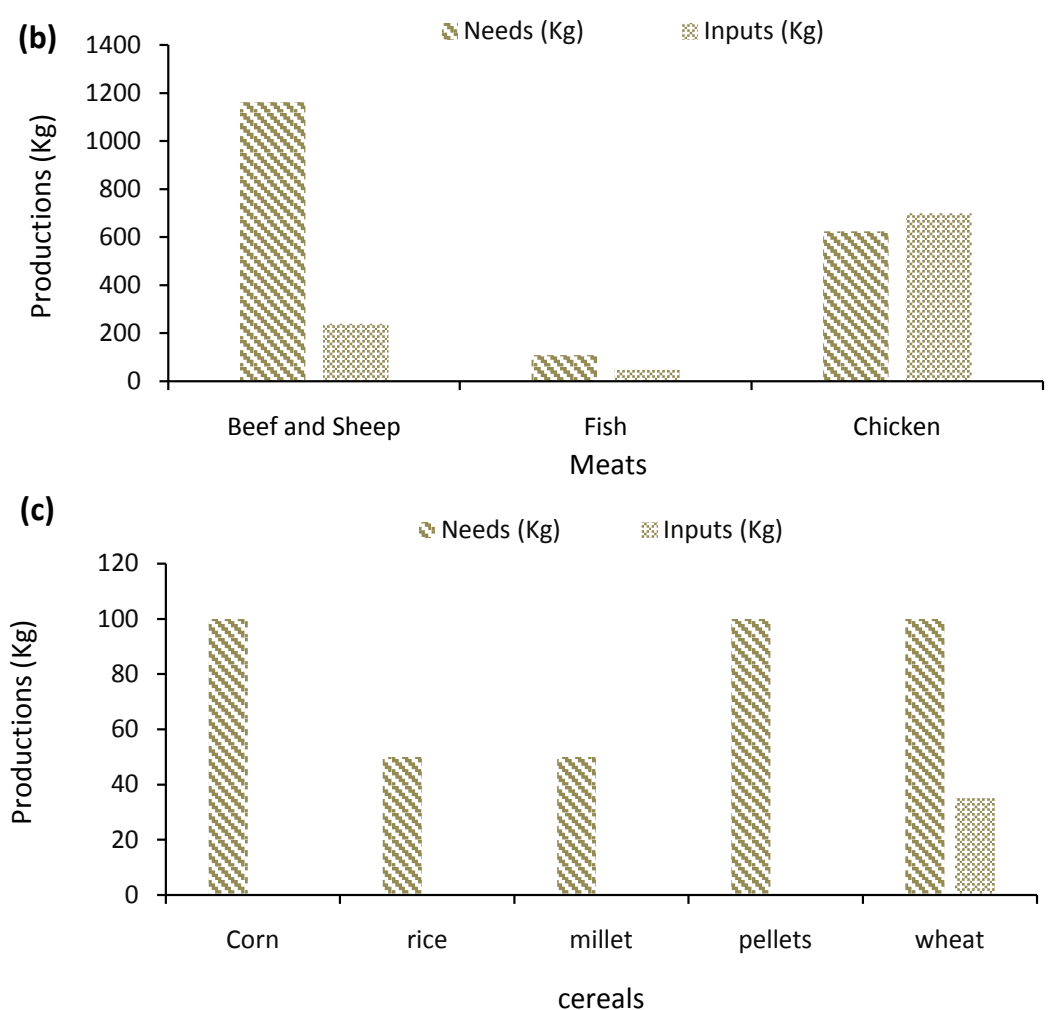

Figure 3. Food needs of the zoo and donations from agrifoods per month (a) fruits, (b) meats (c) cereals.

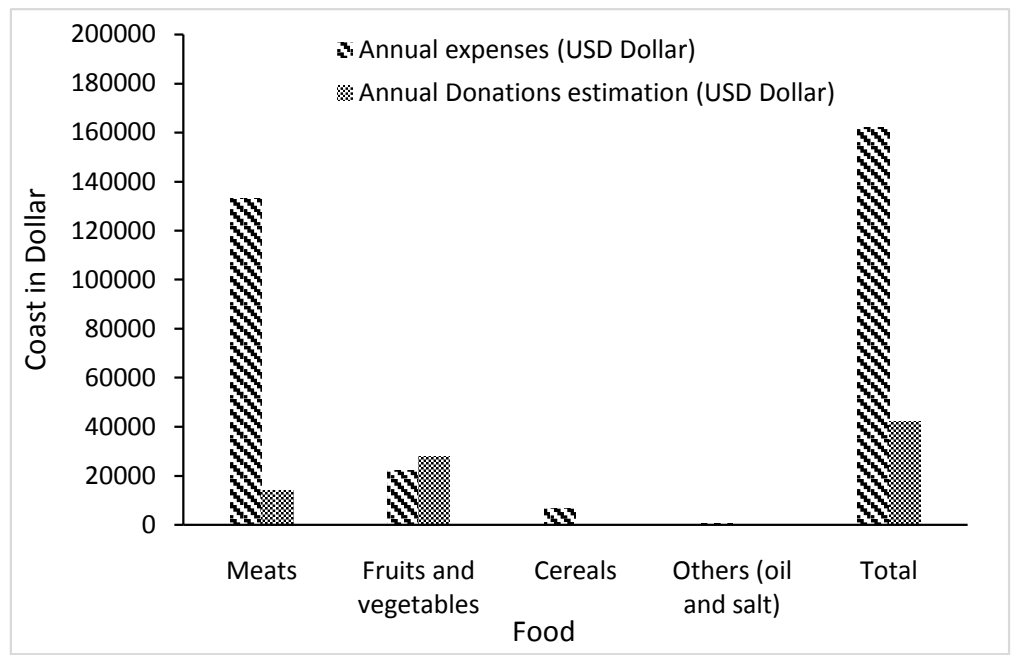

Figure 4. Financial impact of unsold items at the zoo.

\section{2) Impact of unsold products on animal mortality}

The impact of the use of unsold products from SCB, SOCOCE and COQIVOIRE/SIPRA on animal mortality from 2011 to 2019 is illustrated by Figure 5 . One could observe that mortality of animals decrease from 22 down to 02 during all these years from 2012 to 2015, a roughly constant death rate. However, since 2016, there has been a sharp decline in animal mortality at the zoo, which fell from 10 in 2016 down to 2 in 2019. 


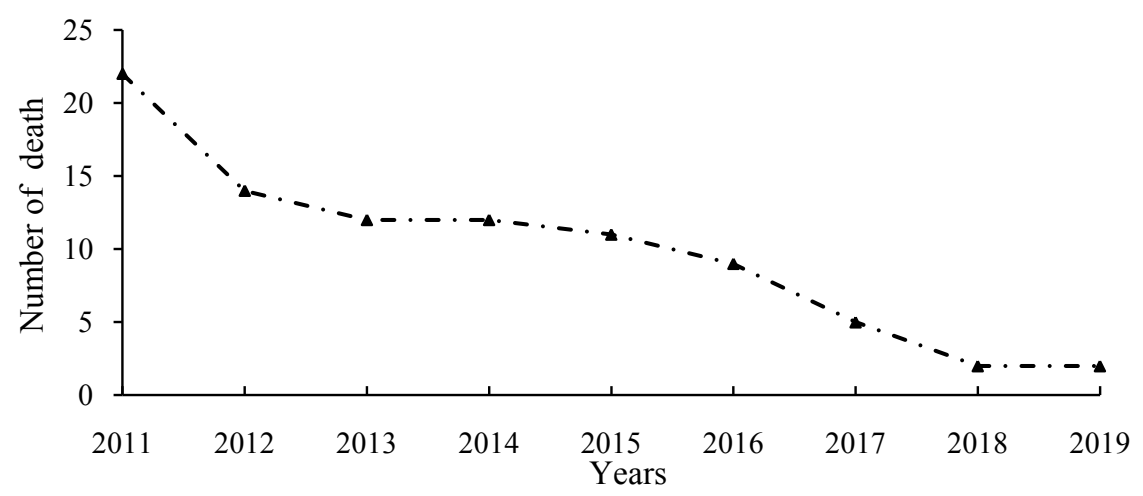

Figure 5. Trend in the number of animal deaths at the Abidjan zoo from 2011 to 2019.

\section{3) Impact of unsold items on the birth in the zoo from 2011 to 2019}

Figure 6 shows the number of births of animals over the period from 2011 to 2019. From 2011 to 2015, there were hardly no births. However, from 2016 to 2019 birth in mammals increased from 03 up to 13 per year.

\section{Discussion}

The compositions and quantities of unsold products of SOCOCE, SCB and COQIVOIRE/SIPRA were determined as well as their impact on the nutrition of the animals at the Abidjan zoo. Several types of unsold products were identified in the structures. At SOCOCE, the main unsold fruits and vegetables (watermelon, melon, radish, cauliflower, turnip, grape, kiwi), to which are added bread, as a vegetable product, and Animal By-Products which are made up of meat, fish, milk and egg products. The unsold food given to the Zoo by this agro-industry tends toward those utilized in zoo animal feeding programs [14]. Their Presence in SOCOCE waste would be due to the fact that foodstuffs are withdrawn from their market because of the deadlines (DLUO) or in consumption times when the products have lost their packaging during transport and poorly preserved products. According to [5], in developing countries, there is a greater loss of food products due to poor storage conditions, insufficient infrastructure and transport, poor packaging or technical equipment. Concerning SCB, fruit sorting deviations (non-exportable fruit) and fruit waste (debris of pads, stems or fruit that cannot be eaten) are the two types of waste identified. These fruit sorting discrepancies are removed from the export channel because they don't meet export standards. SIPRA waste is composed of whole salted chickens, smoked or not, legs, necks and cold cuts. All these unsold products are withdrawn from sales circuit because of the DLUO or the DLC and constitute waste to be recovered. Estimates of quantities of unsold products from the three structures revealed very significant deposits. The most important food groups in agrifood's food waste generation are fruit and vegetables as well as cereals, followed by dairy products, whereas the share of meat and fish in total food waste is relatively small. These observations are in agreement with those of [15] who worked on food waste prevention in Europe. The lack of cereals in the unsold products of 


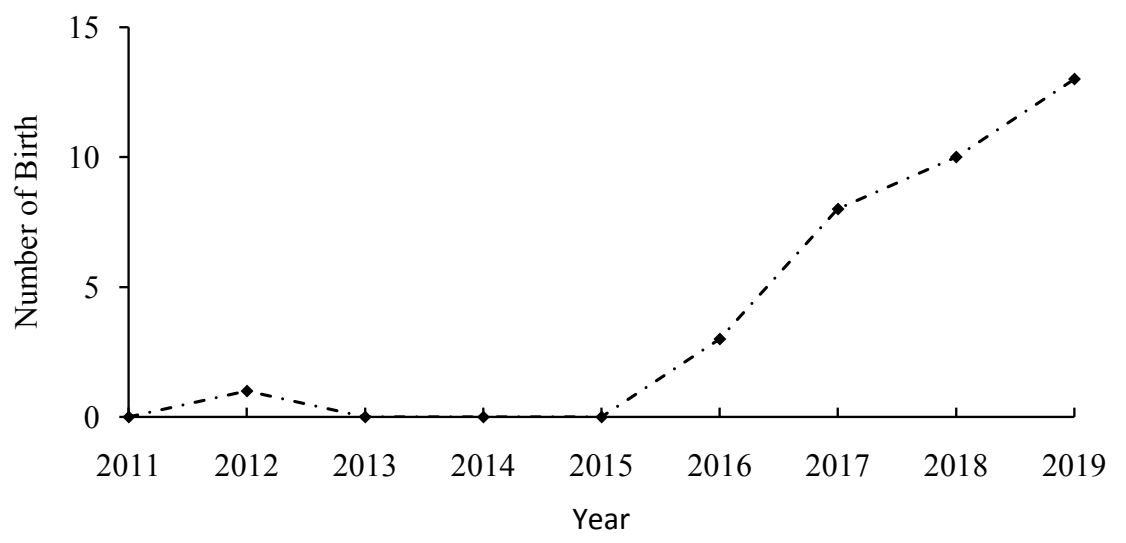

Figure 6. Evolution curve of the number of births of animals at the Abidjan zoo from 2011 to 2019.

the companies could be due to the relatively low costs of these products in the supermarkets, by their strong consumption by the population, but especially by their long deadline of consumption. SOCOCE's unsold deposit is estimated at thirty-six (36) tons of waste per year left at the zoo for the feeding of these animals. These quantities are close to those of several supermarkets [16] [17] [18] [19]. At SCB, the deposit of non-exportable fruits in the packaging centers is estimated at two (02) tons and the fruit waste at one ton. This amount of fruit waste depends on several criteria such as wind, sunlight [20]. Zoo takes 20 cases of bananas per trip or $400 \mathrm{~kg}$ [20]. Deposits of COQIVOIRE /SIPRA are estimated at three (03) tons per month and zoo recovers 10 tonnes and even more per years. The deposits being important the demand of zoo is always satisfied. The use of unsold food to feed zoo's animals has had an impact on financial level, on mortality rate and on reproduction of the animals. The zoo makes annual expenses reduction of $25.94 \%$ because the food that the zoo would normally buy is given to it free of charge, allowing it to make savings. This gain allows the zoo to invest in animal habitat to improve animal adaptation, health and welfare. Regarding the impact of unsold products on animal mortality, an overall decrease in mortality was observed. This number has decreased from 22 down to 02 over the period from 2011 to 2019 . This reduction in the mortality rate at the Abidjan zoo would be allocated to better feeding, which would be explained by the use of the quantity and quality of unsold food from the three structures. It should be noted that the wide variety of fruits and vegetables and other products provided by the structures to zoo constitutes a sufficient quantity for the animals. This quality and quantity of waste being varied, avoids mortality, because the animals are faced with a choice of food very diverse from what they would have in the wild, and especially in situations that they do not control. Vegetable wastes from unsold food are good sources of both crude protein and energy, especially for ruminant animals according to [10]. Pulp cabbage leaves, and potato have around or more than 20\% Crude Protein [21]. Remaining Vegetable contain Crude Protein (CP) between 10 and 19\%, except carrot pulp have less than 
$10 \%$ CP [22]. Moreover, these unsold foods are sorted, washed and preserved in excellent hygienic conditions. This prevents the animals from consuming pathogens that could harm their health. The works of [23] shows that a poor diet makes animals susceptible to a whole spread of pathogens to which the wellnourished animal is resistant. [24] has shown that adequate supply of nutrient ensures good digestive function, good growth, constant adult weight, good reproductive performance, and effective defense against infection and infestation. There is a general increase in the number of births of animals over the period from 2011 to 2019 due to improved feeding. Some vegetables as tomatoes had a good effect on performance and plasma and egg yolk cholesterol contents [25]. This result would be due to the good feeding of the animals by the unsold products of these structures because a diet low in energy and protein would cause reproductive disorders [23] [26]. According to several studies animals in poor condition or losing weight generally have disappointing reproductive performance (abortion, lower birth rate) [14] [27]. Energy provided by food promotes the act of mating [28]. Morever, unsold items can also have an indirect impact on the reproductive health of animals. In fact, the funds made by the zoo are reinvested in order to improve their living environment. So this money is used to keep the boxes clean. It is also used in the medical care of animals. These observations are confirmed by the increase of the animal population from 151 to 310 animals in 8 years.

\section{Conclusion}

This study characterized and estimated the waste from the SCB, SOCOCE and COQIVOIRE and their impact on Abidjan Zoo animals' health. With an estimated population of 151 individuals, the animals of Abidjan Zoo have an estimated annual food requirement of 14,220, 22,752 and 4.8 tons per year for fruits, meat and cereals respectively. The three selected structures have a large quantity of quality waste that is actually used to feed the animals of the Zoo of Abidjan. The use of unsold food from the three agribusinesses results in a $25 \%$ savings in the feed budget. This makes it possible to use this surplus money to improve the welfare of the animals, health care, and maintenance of their housing. The cost of food for zoological institutions is often targeted as an area for savings, which have a long-term coast to the health of the animals. Thus, this study shows that cost savings can be achieved without compromising animal health. Also, the variety of feeds and their nutritional quality have an impact on the mortality and reproductivity of animals. The monitoring of mortality since the use of unsold food in the animals' diet from 2011 to 2019, shows a 90\% decrease in mortality in the Zoo. One could observe an increase in births from 0 in 2011 to more than 12 in 2019. It is therefore clear that the efficient use of unsold goods can prevent waste. And on the other hand, help in a context of sustainable development of the zoological park of Abidjan to fulfill its functions of species conservation, recreation, education and research. 


\section{Acknowledgements}

Thanks to the managers of Abidjan ZOO, and the three Agri-food Industries (SOCOCE, COQUIVOIRE and SCB) in Abidjan for facilitating and assisting in the data collecting in this study.

\section{Conflicts of Interest}

The authors declare no conflicts of interest regarding the publication of this paper.

\section{References}

[1] Hoornweg, P. and Bhada-Tata, D. (2012) What a Waste: A Global Review of Solid Waste Management. Urban Development Series Knowledge Papers. World Bank, Washington DC, 116.

[2] O’Donnell, T.H., Deutsch, J., Yungmann, C., Zeitz, A. and Katz, S.H. (2015) New Sustainable Market Opportunities for Surplus Food: A Food System-Sensitive Methodology (FSSM). Food and Nutrition Sciences, 6, 883-892. https://doi.org/10.4236/fns.2015.610093

[3] FAO (2013) Food Wastage Footprint: Impacts on Natural Resources; Summary Report. Natural Resources Management and Environment Department, Rome, $61 \mathrm{p}$.

[4] Abiad, M.G. and Meho, L.I. (2018) Food Loss and Food Waste Research in the Arab World: A Systematic Review. Food Security, 10, 311-322. https://doi.org/10.1007/s12571-018-0782-7

[5] Seberini, A. (2020) Economic, Social and Environmental World Impacts of Food Waste on Society and Zero Waste as a Global Approach to Their Elimination. SHS Web of Conferences, 74, Article No. 03010. https://doi.org/10.1051/shsconf/20207403010

[6] Gustavsson, J., Cederberg, C., Sonesson, U., van Otterdijk, R. and Meybeck, A. (2011) Global Food Losses and Food Waste. FAO, Rome, 29 p.

[7] Berjan, S., Capone, R., Debs, P. and El Bilali, H. (2018) Food Losses and Waste: A Global Overview with a Focus on Near East and North Africa Region. International Journal of Agricultural Management and Development, 8, 1-16.

[8] Smith, P., Haberl, H., Popp, A., Erb, K.-H., Lauk, C., Harper, R., Tubiello, F.N., de Siqueira Pinto, A., Jafari, M., Sohi, S., Masera, O., Böttcher, H., Berndes, G., Bustamante, M., Ahammad, H., Clark, H., Dong, H., Elsiddig, E. A, Mbow, C., Ravindranath, N.H., Rice, C.W., Robledo Abad, C., Romanovskaya, A., Sperling, F., Herrero, M., House, J.I. and Rose, S. (2013) How Much Land-Based Greenhouse Gas Mitigation Can Be Achieved without Compromising Food Security and Environmental Goals? Global Change Biology, 19, 2285-2302. https://doi.org/10.1111/gcb.12160

[9] Renaud, B. (2015) Valoriser des coproduits issus de l'industrie alimentaire en alimentation animale: Réglementation et leviers possibles. Innovation Agronnomique, 48, 233-239.

[10] Bakshi, M.P.S., Wadhwa, M. and Makkar, H.P.S. (2016) Waste to Worth: Vegetable Wastes as Animal Feed. CAB Reviews, 11, 1-26. https://doi.org/10.1079/PAVSNNR201611012

[11] Chapoutot, P., Rouillé, B., Sauvant, D. and Renaud, B. (2019) Les coproduits de l'industrie agro-alimentaire: Des ressources alimentaires de qualité à ne pas négliger. 
INRAE Productions Animales, 31, 201-220.

https://doi.org/10.20870/productions-animales.2018.31.3.2353

[12] Grote, U. (2004) Can We Improve Global Food Security? A Socio-Economic and Political Perspective. Food Security, 6, 187-200.

https://doi.org/10.1007/s12571-013-0321-5

[13] Deem, S.L. (2007) Role of the Zoo Veterinarian in the Conservation of Captive and Free-Ranging Wildlife. International Zoo Yearbook, 41, 3-11. https://doi.org/10.1111/j.1748-1090.2007.00020.x

[14] Edwards, M.S. (2003) Nutrition of Zoo Animals. Recent Advances in Animal Nutrition in Australia, 14, 1-9.

[15] Priefer, C., Jörissen, J. and Bräutigam, K.-R. (2016) Food Waste Prevention in Europe-A Cause-Driven Approach to Identify the Most Relevant Leverage Points for Action. Resources, Conservation and Recycling, 109, 155-165. https://doi.org/10.1016/j.resconrec.2016.03.004

[16] Smil, V. (2004) Improving Efficiency and Reducing Waste in Our Food System. Environmental Sciences, 1, 17-26. https://doi.org/10.1076/evms.1.1.17.23766

[17] FAO (2011) Global Food Losses and Food Waste-Extent, Causes and Prevention. Rome, $37 \mathrm{p}$.

[18] Bilska, B., Piecek, M. and Kołozyn-Krajewska, D. (2018) A Multifaceted Evaluation of Food Waste in a Polish Supermarket-Case Study. Sustainability, 10, 3175. https://doi.org/10.3390/su10093175

[19] Nikolicic, S., Kilibarda, M., Maslaric, M., Mircetic, D. and Bojic, S. (2021) Reducing Food Waste in the Retail Supply Chains by Improving Efficiency of Logistics Operations. Sustainability, 13, 6511. https://doi.org/10.3390/su13126511

[20] SCB (2018) Rapport d'activité RSE 2018 SCB. Rapport d'activité RSE 2017 SCB Societe d'etude et de developpement de la Culture Bananiere Cote d'Ivoire.

[21] Wadhwa, M. and Bakshi, M.P.S. (2005) Vegetable Wastes-A Potential Source of Nutrients for Ruminants. Indian Journal of Animal Nutrition, 22, 70-76.

[22] Nalecz-Tarwacka, T., Karaszewska, A. and Zdziarski, K. (2003) The Influence of Carrot Addition to Cow's Ration on the Level of Vitamins and Fatty Acids in Cow Milk. Polish Journal of Food Nutrition Science, 12, 53-56.

[23] Ranjet, K. and Kurup, B.M. (2013) Economic Analysis of Polder Based Freshwater Prawn Farming Systems in Kuttanad, India. International Journal of Agricultural Policies and Practices, 1, 17-27.

[24] Oftedal, O.T. and Allen, M.E. (1996) Essential Nutrients in Mammalian Diets. In: Kleiman, D.G., Allen, M.E., Thompson, K.V. and Lumpkin, S., Eds., Wild Mammals in Captivity: Principles and Techniques. Part 2: Nutrition, University of Chicago Press, Chicago, 117-128.

[25] Nobakht, A. and Safamehr, A.R. (2007) The Effect of Inclusion Different Levels of Dried Tomato Pomace in Laying Hens Diets on Performance and Plasma and Egg Yolk Cholesterol Contents. Journal of Animal and Veterinary Advances, 9, 1101-1106.

[26] Turner, L. (2006) Etude de l'alimentation des gibbons à mains blanches (Hylobates 1. lar) en captivité à la Réserve Africaine de Sigean. Thèse en médecine vétérinaire. Ecole Vétérinaire Alfort, $191 \mathrm{p}$.

[27] Brisson, J. (2003) Nutrition, alimentation de R\& et reproduction. Symposium sur les bovins laitiers. Saint hyacinthe, (Québec), 30 octobre 2003. 66 p.

[28] Malé, C.A. (2007) Étude de l'alimentation de trois espèces de cercopithèques du zoo 
du reynou: Les macaques à face rouge (macaca arctoides), les patas (erythrocebus patas) et les singes verts (cercopithecus aethiops). Thèse de Doctorat vétérinaire, Ecole Nationale Vétérinaire de Toulouse, $140 \mathrm{p}$. 